\title{
Help-Seeking Intention During COVID-19 Pandemic: A Nationwide Web-Based Survey in Indonesia
}

Aprezo Pardodi Maba ${ }^{1 *}$, Mulawarman ${ }^{2}$, Ma'rifatin Indah Kholili ${ }^{3}$, Anugrah Intan Cahyani ${ }^{4}$, Kushendar $^{5}$, Indah Fajrotuz Zahro ${ }^{6}$, Subandi ${ }^{4}$, Maria Natalia Loban ${ }^{7}$, Reza Muttaqin ${ }^{8}$, Nuril Hidayanti S. ${ }^{9}$, Asti Haryati ${ }^{10}$, Arizona ${ }^{11}$, Yekti Endah Pambudi ${ }^{12}$, Widya Juwita Sari ${ }^{13}$, Dwi Bhakti Indri M. ${ }^{14}$

\footnotetext{
${ }^{1}$ Institut Agama Islam Ma'arif NU (IAIMNU) Metro Lampung, Indonesia

${ }^{2}$ Universitas Negeri Semarang, Indonesia

${ }^{3}$ Universitas Sebelas Maret, Indonesia

${ }^{4}$ Universitas Islam Negeri Raden Intan, Indonesia

${ }^{5}$ Universitas Islam Negeri Raden Fatah, Indonesia

${ }^{6}$ Sekolah Tinggi Agama Islam At-tanwir Bojonegoro, Indonesia

${ }^{7}$ Institut Agama Kristen Negeri Kupang, Indonesia

${ }^{8}$ Universitas Islam Negeri Ar-Raniry, Indonesia

${ }^{9}$ Institut Agama Islam Negeri Samarinda, Indonesia

${ }^{10}$ Institut Agama Islam Negeri Bengkulu, Indonesia

${ }^{11}$ Universitas PGRI Palembang, Indonesia

${ }^{12}$ Institut Agama Islam Negeri Salatiga, Indonesia

${ }^{13}$ Universitas Negeri Yogyakarta, Indonesia

${ }^{14}$ Institut Pesantren KH. Abdul Chalim Mojokerto, Indonesia
}

Corresponding author: aprezo@iaimnumetrolampung.ac.id / aprezopm@gmail.com * 


\begin{abstract}
$\underline{\text { Abstract }}$
Background: This study was conducted based on many studies on mental health problems during the Covid-19 pandemic and the urgency for the availability of mental health services. Unfortunately, research related to help-seeking intention for mental health in general public, particularly in Indonesia, is very limited. Meanwhile, several studies have shown that helpseeking intention is a good predictor whether someone will attend mental health services or not.
\end{abstract}

Objective: The aims of this study are to determine the sources of help that are most soughtafter and the factors predicting help-seeking intention during the COVID-19 pandemic.

Methods: Online instruments consist of demographical questions, 11 items of General Helpseeking Questionnaire (GHSQ) (Wilson, Deane, Ciarrochi, \& Rickwood, 2005), 7 items of Fear of COVID-19 Scale (FCV-19S) (Ahorsu et al., 2020), and 5 items of Coronavirus Anxiety Scale (CAS) (Lee, 2020) were distributed via email, Facebook messenger, and Whatsapp during August 11 -21, 2020. The data were analyzed using multiple linear regression and multivariate logistic regression.

Results: The results showed that parents were the most sought-after source of help during the COVID-19 pandemic. While age, education, occupation, living in infected area, and fear significantly predict help-seeking intention. Meanwhile, the factors significantly predict the level of help-seeking intention are anxiety and fear.

Limitations: This research uses a cross-sectional design. Therefore, it cannot test helpseeking intention after data collection. Furthermore, data was obtained using the self-report method which depends on the participants' ability to understand the items of the questionnaire.

Conclusion: The results showed that parents were the main choice of the participants if they seek for help. Therefore, it is important for parents to be equipped with skills in providing mental health help for their children or relatives. Moreover, all parties should be equipped and trained to provide mental health help. Mental health services should be provided to various demographical background of general public during of COVID-19 pandemic. The attention of mental health services should be directed to the not infected area as well rather than infected area only.

Keywords: anxiety; COVID-19; fear; general public; help-seeking intention. 


\section{Introduction}

The 2019 novel coronavirus (COVID-19) was declared a pandemic by the World Health Organization (WHO) and has become a global attention (Wang et al., 2020). Furthermore, medical personnel, mental health professionals, researchers, observers and others are all working together to find solutions in order to minimize the impact. All authorities have appealed to everyone to do self-quarantine, frequent hand washing, closing schools and campuses, conducting social distancing, wearing masks, and closing all crowded places, apart from hospitals and similar medical services. Moreover, some countries have adopted lockdown policies.

This is due to the fact that the virus spreads rapidly. It can be seen in the increasing number of people infected. As per August 7, 2020, there were 18,614,177 confirmed cases in all countries, while the death toll reached 702,642 (WHO, 2020b). However, it is believed that this number is still far below the true figure (Baud et al., 2020). In Indonesia, the first case was confirmed by the president on March 2, 2020 and within one month, the confirmed cases became 1,789 with 112 people recovering and 170 deaths (Djalante et al., 2020). Presently (August 25, 2020), the total number of positive cases is 157,859 with 112,867 recovered and 6,858 deaths (Penanganan COVID-19, 2020b).

This situation is exacerbated by the news about the lack of government response and preparedness (Djalante et al., 2020; Garrett, 2020; Setiati \& Azwar, 2020), the threat of poverty and criminal acts (Mariska, 2020), as well as the return of citizens abroad to Indonesia (Pradana, Syahputra, Wardhana, Kartawinata, \& Wijayangka, 2020). Which continues to be disseminated massively by the local mass media. This makes people feel even more threatened (Mian \& Khan, 2020), thus causing various mental health impacts on the general public.

The mental health impact does not only affect medical personnel who directly treat infected patients, but also to the general public (Ornell, Schuch, Sordi, \& Kessler, 2020; Roy et al., 2020). Furthermore, perceived mental health disorders includes: anxiety, worry, fear of contact with other people, stigmatization, discrimination, depression, stress, obsessive compulsiveness, phobic anxiety, and feelings of loss (Ahorsu et al., 2020; Fernández, Crivelli, Guimet, Allegri, \& Pedreira, 2020; Huang \& Zhao, 2020; Ifdil, Fadli, Suranata, Zola, \& Ardi, 2020; Lin, 2020; Pappas, Kiriaze, Giannakis, \& Falagas, 2009; Wang et al., 2020; Xiong et al., 2020; Zhao et al., 2020). In Indonesia, the anxiety felt due to the Covid-19 pandemic is increasingly visible (Wulandari \& Hidayat, 2020), and more people seek mental health assistance because they feel they are experiencing mental health disorders (Abdullah, 2020). In some areas, there have even been cases of suicide after they were dismissed from their workplace due to the COVID-19 pandemic crisis (Gunadha, 2020). In addition, it has increased fear and anxiety in the community.

The response to COVID-19 is still focused on how to stop the infection and treatment for infected patients. Furthermore, this can be seen from the call for prevention and efforts to make the virus vaccine (Dhama et al., 2020; Dong, Hu, \& Gao, 2020; Iqbal Yatoo et al., 2020). The WHO has issued a protocol to support public mental health during the pandemic 
(WHO, 2020a) and several national-level health authorities such as China have followed suit by providing guidelines on mental health treatment for infected patients (Duan \& Zhu, 2020). They have provided interventions to help infected patients, unfortunately, these are still limited to infected patients only. Meanwhile, those under quarantine and the medical team are yet to receive adequate treatment (Xiang et al., 2020). In Indonesia, policies have been put in place to stop the spread of corona virus. However, the mental health is yet to receive enough attention and this leaves an opening for further research.

Based on the mental health conditions experienced by people during the pandemic, many researchers and scientists are campaigning for the urgent provision of mental health services to infected patients (Ahorsu et al., 2020; Duan \& Zhu, 2020; Fernández et al., 2020; Huang \& Zhao, 2020; Ifdil et al., 2020; Lin, 2020; Pappas et al., 2009; Wang et al., 2020; Xiong et al., 2020; Zhao et al., 2020), especially online mental health treatment (Wind, Rijkeboer, Andersson, \& Riper, 2020). In Indonesia, mental health professionals independently take the initiative to provide mental health assistance, such as making infographics on the prevention of corona virus and provide a free online counseling for general public (Ifdil et al., 2020).

However, based on the research that was previously mentioned, nothing has been discussed concerning the help-seeking intention. Most researchers campaign on the importance of providing help for mental health problems during COVID-19 pandemic. Otherwise, it is important for the mental health services to know the help-seeking intention among general public. People will not take advantage of the mental health services if they have no interest in seeking mental health help.

People with mental health problems should have a desire to seek help, either from formal or informal sources. However, most of them reluctant to do so and tend to avoid it (Abdollahi, Hosseinian, Beh-Pajooh, \& Carlbring, 2017; Corrigan, 2004). For instance, a factor that can prevent someone from seeking help when experiencing mental health problems is the stigma given to them (Corrigan, 2004; Topkaya, Vogel, \& Brenner, 2017; Vogel, Wade, \& Haake, 2006; Yap, Wright, \& Jorm, 2011). Furthermore, finance can also be a barrier when seeking help, particularly from a formal source (Czyz, Horwitz, Eisenberg, Kramer, \& King, 2013). Several related studies in Indonesia show that intention to seek help from formal sources is relatively low because they prefer to get help from non-formal sources such as friends and family (Setiawan, 2006).

The planned behaviour theory is commonly cited in studies that involves seeking help intention (Ajzen, 2002). The intention to seek help is closely related in predicting helpseeking behavior (Dschaak, Spiker, Berney, Miller, \& Hammer, 2019; Spiker, Berney, Hammer, \& Jensen, 2020). Therefore, the higher a person's intention, the more the likelihood behavior related to that desire will occur.

Based on the previous mentioned literature limitation, authors were focused on helpseeking intention during COVID-19 pandemic. Authors will look at their intention to seek help from formal sources (counselors and psychologists), non-formal sources (spouses, parents, friends, or relatives), and factors that could predict help-seeking intention. The 
results obtained is expected to provide an overview for mental health practitioners and policy makers in formulating appropriate intervention models for people with mental health problems due to the COVID-19 pandemic.

\section{Methods}

\section{Procedures and Participants}

During August 11-21, 2020, authors disseminated online self-reported questionnaires to general public in Indonesia. Participants were invited via personal email, Whatsapp, and Facebook messenger. If they agreed, they will be asked to fill out self-reported questionnaires. All agreed participants were 1,350 from various backgrounds (Female $=977$, Male $=373$ ).

After initial examination of the data, 10 responses were excluded because we found they responses were outliers. Finally, 1,340 $($ Female $=971$, Male $=369)$ responses were used for analysis. The authors use the minimum number of samples with scale 10:1, at least 10 participants for each variable (Hair, Hult, Ringle, \& Sarstedt, 2016). This means the amount of data meet the sample size standard.

\section{Instrument}

Demographical questions such as gender, age, education, occupation, living in infected area, smoking, and alcohol use were given to the participants. Furthermore, the General Help-seeking Questionnaire (GHSQ) (Wilson et al., 2005), Fear of COVID-19 Scale (FCV-19S) (Ahorsu et al., 2020), dan Coronavirus Anxiety Scale (CAS) (Lee, 2020). Initially, GHSQ, FCV-19S, and CAS were English instruments but later authors conducted instruments adaptation to Bahasa Indonesia (local language) based on the guidelines was made by the International Test Commission (Bartram et al., 2018). At the test development stage, the instruments were translated by two authors (A and B) who can use English and local language. The author A translated into Bahasa Indonesia, while B translated back to English.

The GHSQ consists of 11 items to determine the tendency to seek help from various sources, both formal (counselors, psychologists, doctors) and non-formal (spouses, parents, friends, relatives) when experiencing mental health problems. Furthermore, COVID-19 pandemic phrases were added to properly suit the research context (Wilson et al., 2005). The instruction goes like this "If you have emotional problems such as fear or anxiety during the COVID-19 pandemic, how likely are you to seek help from the following sources? Help can be provided in person or online. Please provide your feedback by selecting the number $(1=$ highly unlikely to 7 = very likely) that best describes your intention to seek help from each of the assistance sources listed below". Furthermore, the higher score indicates higher intention to seek help. This instrument is stable to measure constructs according to the context of the 
study, for instance suicidal thoughts $(\alpha=.83)$ and emotional problems $(\alpha=.70)$. Though, in this study the internal reliability was appropriate $(\alpha=.81)$.

FCV-19S (Ahorsu et al., 2020) to determine the fear experienced by the participats. It consists of 7 items with five alternative choices ( $1=$ strongly disagree to $5=$ strongly agree). Examples of the statements are "It makes me uncomfortable to think about coronavirus" and "I am afraid of losing my life because of coronavirus". The higher the score, the higher fear experienced. The initial reliability of the FCV-19S was as good $(\alpha=.82)$ as the one used during the research $(\alpha=.90)$.

CAS (Lee, 2020) was used to determine the anxiety experienced by participants. It consists of five items with five choices ( $1=$ never to $5=$ almost every day). Examples the statements are "I felt dizzy, lightheaded, or faint, when I read or listened to news about the coronavirus" and "I had trouble falling or staying asleep because I was thinking about the coronavirus". The higher the score, the higher anxiety experienced. The initial reliability of CAS was good $(\alpha=0.93)$ and same goes for the one used during the research $(\alpha=.87)$.

\section{Data analysis}

Data were analyzed with SPSS 16. Descriptive analysis was used to characterize demographics, fear, anxiety, and GHSQ scores of the participants. Furthermore, the normality test was performed using the Kolgomorov Smirnov and multicollinearity by looking at VIF < 10. The research variables were tested using multiple linear regression after meet the assumption test. In addition, a multivariate logistic regression was conducted to see the factors that can predict moderate and high GHSQ scores.

\section{Results and Discussion}

\section{Demographic characteristics of respondents}

As shown in Table 1, all participants who were categorized based on gender, age, education, occupation, living in infected area, smoking, and alcohol use. Furthermore, each category is given a percentage and divided in to three level of help-seeking intention. Meanwhile, Table 2 shows that parents are the most sought-after source of assistance followed by doctors, mental health experts (counselors, psychiatrists, psychologists), friends, family (other than parents), help by telephone, religious leaders (kyai, ulama, pastor and others), spouses (husband/wife or girlfriend), teachers, and social workers.

\section{Classic assumption test}

Two criteria were used in the classic assumption test for the multiple linear regression, namely the residual value or error should be normally distributed with the Kolmogorov smirnov significance ( $\mathrm{p}>$.05) (Field, 2013; Stevens, 2012) and there is no multicollinearity by looking at the VIF value $<10$ ( Alin, 2010). Based on the classical 
assumption test, it is believed that the residual value is distributed based on the Kolgomorov Smirnov test ( $p>$.05) and all VIF values are less than 10 (Alin, 2010). The result of classic assumption test showed all assumptions are met the criteria, thus the regression analysis can be done.

\section{Multiple regression test and logistic regression}

To determine factors that predict help-seeking intention, multiple linear regression analysis based on age, gender, education, occupation, living in infected area, smoke, alchohol use, fear, and anxiety was carried out. Furthermore, a significant regression equation was found $(\mathrm{F}(9,1330)=24.576, \mathrm{p}<.000)$, with an $\mathrm{R}^{2}$ of .143 . While the results of partial analysis showed predictors that significantly predict Help-seeking Intention were age $(\mathrm{b}=$ $.054, \mathrm{p}=.042)$, education $(\mathrm{b}=754, \mathrm{p}=.002)$, occupation $(\mathrm{b}=.088, \mathrm{p}=.020)$, living in infected area $(b=-.072, p=.006)$, and fear $(b=.318, p=.000)$. Meanwhile gender $(b=-$ $.039, \mathrm{~b}=.177)$, smoke $(\mathrm{b}=.027, \mathrm{p}=.365)$, alcohol use $(\mathrm{b}=-.052, \mathrm{p}=.059)$, and anxiety $(\mathrm{b}=$ $0.33, \mathrm{p}=.316$ ) were not significantly predict help-seeking intention (Table 3 ). The multivariate logistic regression analysis reveals that there are only two predictors that significantly predict the level of help-seeking intention, namely fear $(\mathrm{OR}=1.062,95 \% \mathrm{CI}=$ $1.035-1.090, \mathrm{p}=.000)$ and anxiety $(\mathrm{OR}=1.045,95 \% \mathrm{CI}=1,003-1,088, \mathrm{p}=.37)$. Meanwhile, other predictors did not show a significant effect on level of help-seeking intention (Table 4).

\section{Discussion}

The result shows that the most sought-after sources of help-seeking intention is parents, followed by doctors, mental health professionals (counselors, psychiatrists, psychologists), friends, family (other than parents), help by telephone, religious leaders (kyai, ulema, pastor and others), spouse (husband / wife or girlfriend), teachers, and social workers. Furthermore, it supports previous study which states that Indonesians tend to seek help from non-formal sources (Setiawan, 2006). It also confirms previous findings that the majority of help-seeking intention in Indonesia is at moderate level (Maba \& Saputra, 2019).

Parents are the most preferred source when someone experiences mental health problems during a pandemic. However, it is affirmed that socio-cultural factors (Han \& Pong, 2015; Hofstede, 1984; Kim \& Lee, 2014) and belief (Song et al., 2019) are significantly affect the help-seeking intention. In addition, Asian countries embrace collectivism culture, including Indonesia (Hofstede, 2001). Furthermore, the stigma and shame if disclosed personal problems to others are also found in Asian people (Han \& Pong, 2015). Individuals were born and raised in collectivist families have a strong emotional connection, therefore they prefer to express their problems to family members such as parents (Hofstede, 1984; Kim \& Lee, 2014).

First of all, the level of help-seeking intention that among the participants is directly related to the COVID-19 pandemic in Indonesia. The predictors such as age, education, 
occupation, living in infected area, and fear significantly predict help-seeking intention. Age group 12-30 has the highest average score of help-seeking among other age groups, while the group of participants in college or above have a higher help-seeking score than the high school or below group. The medical profession has the highest percentage compared to other professions. Furthermore, people whose fear in the high category tend to have higher helpseeking scores than those in the moderate and low categories, and people who living in not infected area tend to have higher help-seeking scores compared to people living in infected area. In addition, the moderate and high levels of help-seeking intention are strongly influenced by feelings of anxiety and fear experienced by the general public.

In Indonesia, area that has no infection of COVID-19 is called by green zone, while yellow zone and red zone are area that exposed by the virus (Penanganan COVID-19, 2020a). Interestingly, people living in green zone showed higher help-seeking intention compared to people living in yellow or red zone. The authors believe that this is caused by the public activities in the green zone are quite different from the yellow and red zone. People who live in green zone relatively have freedom to do activity or to work outside their house (Penanganan COVID-19, 2020c). The authors also speculate that reason for the high helpseeking intention in the green zone is due to the fact that they are still exposed by the news of COVID-19 impact as well as the yellow and red zone (Garrett, 2020; Mian \& Khan, 2020). The mass media continues to report about the lack government preparedness (Garrett, 2020; Setiati \& Azwar, 2020), suicide (Gunadha, 2020), poverty and criminal acts (Mariska, 2020), returning citizen from abroad to Indonesia (Pradana et al., 2020), and the implementation of quarantine or social distancing (Satya, 2020). Therefore, this news massively adds to the anxiety and fear of the general public (Abdullah, 2020) in the green zone even though they have never experienced how people live in the infected area. The results obtained from this research shows that the moderate and high level of help-seeking intention is significantly predicted by anxiety and fear. In addition, it confirms the reports that more people are seeking help because they have mental health problems during a pandemic (Abdullah, 2020).

Based on all these findings, non-formal help sources, particularly parents should be equipped and trained the basic mental health helping skills. Mental health services should be provided to various demographical background of general public during of COVID-19 pandemic. The attention of mental health services should be directed to the not infected area as well rather than infected area only.

\section{Limitations}

This research uses a cross-sectional design therefore it cannot test the help-seeking intention after data collection or the design does not allow to do follow-up data. The data was collected using self-report and it really depends on the participants' ability to understand the questions. However, bias in understanding the questions is in high possibility.

\section{References}


Abdollahi, A., Hosseinian, S., Beh-Pajooh, A., \& Carlbring, P. (2017). Self-Concealment Mediates the Relationship Between Perfectionism and Attitudes Toward Seeking Psychological Help Among Adolescents. Psychological Reports, 120(6), 1019-1036. https://doi.org/10.1177/0033294117713495

Abdullah, I. (2020). COVID-19: Threat and Fear in Indonesia. Psychological Trauma: Theory, Research, Practice, and Policy, 12(5), 488. https://doi.org/10.1037/tra0000878

Ahorsu, D. K., Lin, C. Y., Imani, V., Saffari, M., Griffiths, M. D., \& Pakpour, A. H. (2020). The Fear of COVID-19 Scale: Development and Initial Validation. International Journal of Mental Health and Addiction, 1-9. https://doi.org/10.1007/s11469-02000270-8

Ajzen, I. (2002). Constructing a TpB Questionnaire: Conceptual and Methodological Considerations. University of Massachusetts Amherst, Office of Information Technologies. Retrieved from https://pdfs.semanticscholar.org/0574/b20bd58130dd5a961f1a2db10fd1fcbae95d.pdf

Alin, A. (2010). Multicollinearity. Wiley Interdisciplinary Reviews: Computational Statistics, 2(3), 370-374. https://doi.org/10.1002/wics.84

Bartram, D., Berberoglu, G., Grégoire, J., Hambleton, R., Muniz, J., \& van de Vijver, F. (2018). ITC Guidelines for Translating and Adapting Tests (Second Edition). International Journal of Testing, 18(2), 101-134. https://doi.org/10.1080/15305058.2017.1398166

Baud, D., Qi, X., Nielsen-Saines, K., Musso, D., Pomar, L., \& Favre, G. (2020, July 1). Real estimates of mortality following COVID-19 infection. The Lancet. Infectious Diseases. NLM (Medline). https://doi.org/10.1016/S1473-3099(20)30195-X

Corrigan, P. (2004). How stigma interferes with mental health care. American Psychologist, 59(7), 614. https://doi.org/10.1037/0003-066X.59.7.64

Czyz, E. K., Horwitz, A. G., Eisenberg, D., Kramer, A., \& King, C. A. (2013). Self-reported Barriers to Professional Help-seeking Among College Students at Elevated Risk for Suicide. Journal of American College Health: J of ACH, 61(7), 398-406. https://doi.org/10.1080/07448481.2013.820731

Dhama, K., Sharun, K., Tiwari, R., Dadar, M., Malik, Y. S., Singh, K. P., \& Chaicumpa, W. (2020, June 2). COVID-19, an emerging coronavirus infection: advances and prospects in designing and developing vaccines, immunotherapeutics, and therapeutics. Human Vaccines and Immunotherapeutics. Taylor and Francis Inc. https://doi.org/10.1080/21645515.2020.1735227

Djalante, R., Lassa, J., Setiamarga, D., Sudjatma, A., Indrawan, M., Haryanto, B., ... Warsilah, H. (2020). Review and analysis of current responses to COVID-19 in Indonesia: Period of January to March 2020. Progress in Disaster Science, 6, 100091. https://doi.org/10.1016/j.pdisas.2020.100091

Dong, L., Hu, S., \& Gao, J. (2020). Discovering drugs to treat coronavirus disease 2019 (COVID-19). Drug Discoveries \& Therapeutics, 14(1), 58-60. https://doi.org/10.5582/ddt.2020.01012

Dschaak, Z. A., Spiker, D. A., Berney, E. C., Miller, M. E., \& Hammer, J. H. (2019). Collegian help-seeking: the role of self-compassion and self-coldness. Journal of Mental 
Health. https://doi.org/10.1080/09638237.2019.1677873

Duan, L., \& Zhu, G. (2020, April 1). Psychological interventions for people affected by the COVID-19 epidemic. The Lancet Psychiatry. Elsevier Ltd. https://doi.org/10.1016/S2215-0366(20)30073-0

Fernández, R. S., Crivelli, L., Guimet, N. M., Allegri, R. F., \& Pedreira, M. E. (2020). Psychological distress associated with COVID-19 quarantine: Latent profile analysis, outcome prediction and mediation analysis. Journal of Affective Disorders, 277, 75-84. https://doi.org/10.1016/j.jad.2020.07.133

Field, A. (2013). Discovering statistics using IBM SPSS statistics. Retrieved from https://books.google.com/books?hl=en\&lr=\&id=c0Wk9IuBmAoC\&oi=fnd\&pg=PP2\&d $\mathrm{q}=$ andy+field+discovering+statistics+using+spss\&ots=LbIpHKXu2D\&sig=37JKDs4I_6 hXJrq9Td-xkPLm9DQ

Garrett, L. (2020). COVID-19: the medium is the message. The Lancet, 395(10228), 942943. https://doi.org/10.1016/S0140-6736(20)30600-0

Gunadha, R. (2020). Kena PHK imbas virus corona, buruh tewas bunuh diri. Retrieved August 25, 2020, from https://jatim.suara.com/read/2020/04/16/154356/kena-phkimbas-virus-corona-buruh-tewas-bunuh-diri

Hair, J., Hult, G., Ringle, C., \& Sarstedt, M. (2016). A primer on partial least squares structural equation modeling (PLS-SEM). Retrieved from https://books.google.com/books?hl=en\&lr=\&id=JDWmCwAAQBAJ\&oi=fnd\&pg=PP1 \&ots=eiPVHiLUVH\&sig=cWYjmu4pWB5E6rvd6CpZ5IQydHY

Han, M., \& Pong, H. (2015). Mental health help-seeking behaviors among Asian American community college students: The effect of stigma, cultural barriers, and acculturation. Journal of College Student Development, 56(1), 1-14. https://doi.org/10.1353/csd.2015.0001

Hofstede, G. (1984). Culture's Consequences: International Differences in Work-Related Values. United States: SAGE Publications Inc. Retrieved from https://books.google.co.id/books?hl=id\&lr=\&id=Cayp_Um4O9gC\&oi=fnd\&pg=PA13\& $\mathrm{dq}=$ Culture $\% 27 \mathrm{~s}+$ consequences:+International+differences+in+workrelated+values\&ots $=$ V4KGDyNOO9\&sig=JRgDv7sde2roe3WV6YYw2J4TYJI\&redir_ $\mathrm{esc}=\mathrm{y} \# \mathrm{v}=$ onepage $\& \mathrm{q}=$ Culture's consequences $\% 3 \mathrm{~A}$ Intern

Hofstede, G. (2001). Culture's consequences: Comparing values, behaviors, institutions and organizations across nations. Sage publications. Retrieved from https://books.google.co.id/books?hl=en\&lr=\&id=9HE-

DQAAQBAJ\&oi=fnd\&pg=PP1\&dq=Hofstede, + G. $+(2001) .+$ Culture's + Consequences: + Comparing+Values, + Behaviors, + Institutions+and+Organizations+Across+Nations. + Th ousand+Oaks:+Sage+Publications\&ots=1KxasLu2TP\&sig=o41UAE

Huang, Y., \& Zhao, N. (2020). Generalized anxiety disorder, depressive symptoms and sleep quality during COVID-19 outbreak in China: a web-based cross-sectional survey. Psychiatry Research, 288, 112954. https://doi.org/10.1016/j.psychres.2020.112954

Ifdil, I., Fadli, R. P., Suranata, K., Zola, N., \& Ardi, Z. (2020, June 1). Online mental health services in Indonesia during the COVID-19 outbreak. Asian Journal of Psychiatry. Elsevier B.V. https://doi.org/10.1016/j.ajp.2020.102153 
Iqbal Yatoo, M., Hamid, Z., Parray, O. R., Wani, A. H., Ul Haq, A., Saxena, A., ... Dhama, K. (2020). COVID-19 - Recent advancements in identifying novel vaccine candidates and current status of upcoming SARS-CoV-2 vaccines. Human Vaccines and Immunotherapeutics. Taylor and Francis Inc. https://doi.org/10.1080/21645515.2020.1788310

Kim, P. Y., \& Lee, D. (2014). Internalized model minority myth, asian values, and helpseeking attitudes among Asian American students. Cultural Diversity and Ethnic Minority Psychology, 20(1), 98-106. https://doi.org/10.1037/a0033351

Lee, S. A. (2020). Coronavirus Anxiety Scale: A brief mental health screener for COVID-19 related anxiety. Death Studies, 44(7), 393-401. https://doi.org/10.1080/07481187.2020.1748481

Lin, C.-Y. (2020). Social reaction toward the 2019 novel coronavirus (COVID-19). Social Health and Behavior, 3(1), 1. https://doi.org/10.4103/shb.shb_11_20

Maba, A. P., \& Saputra, A. A. (2019). Intention to Seek Counseling Among Indonesian Students: Examining the Impact of Social Anxiety and Loneliness. Islamic Guidance and Counseling Journal, 2(2), 40-48. https://doi.org/10.25217/igcj.v2i2.434

Mariska, M. A. (2020). COVID-19 \& Its Impacts: Is Indonesia Ready? S. Rajaratnam School of International Studies. Retrieved from http://hdl.handle.net/11540/11920

Mian, A., \& Khan, S. (2020, December 18). Coronavirus: The spread of misinformation. BMC Medicine. BioMed Central Ltd. https://doi.org/10.1186/s12916-020-01556-3

Ornell, F., Schuch, J. B., Sordi, A. O., \& Kessler, F. H. P. (2020, May 1). "“Pandemic fear"” and COVID-19: Mental health burden and strategies. Brazilian Journal of Psychiatry. Associacao Brasileira de Psiquiatria. https://doi.org/10.1590/1516-4446-2020-0008

Pappas, G., Kiriaze, I. J., Giannakis, P., \& Falagas, M. E. (2009, August 1). Psychosocial consequences of infectious diseases. Clinical Microbiology and Infection. Blackwell Publishing Ltd. https://doi.org/10.1111/j.1469-0691.2009.02947.x

Penanganan COVID-19, G. T. P. (2020a). 104 Kabupaten dan Kota Masuk Daftar Zona Hijau. Retrieved August 24, 2020, from https://covid19.go.id/p/berita/104-kabupatendan-kota-masuk-daftar-zona-hijau

Penanganan COVID-19, G. T. P. (2020b). Data COVID-19. Retrieved August 24, 2020, from https://covid19.go.id/

Penanganan COVID-19, G. T. P. (2020c). Tiga Langkah Jitu Bagi Daerah untuk Beralih ke Zona Hijau. Retrieved August 24, 2020, from https://covid19.go.id/p/berita/tigalangkah-jitu-bagi-daerah-untuk-beralih-ke-zona-hijau

Pradana, M., Syahputra, S., Wardhana, A., Kartawinata, B. R., \& Wijayangka, C. (2020). The Effects of Incriminating COVID-19 News on the Returning Indonesians' Anxiety. Journal of Loss and Trauma, 1-6. https://doi.org/10.1080/15325024.2020.1771825

Roy, D., Tripathy, S., Kar, S. K., Sharma, N., Verma, S. K., \& Kaushal, V. (2020). Study of knowledge, attitude, anxiety \& perceived mental healthcare need in Indian population during COVID-19 pandemic. Asian Journal of Psychiatry, 51, 102083. https://doi.org/10.1016/j.ajp.2020.102083

Satya, P. A. I. N. P. (2020). COVID- 19 dan Potensi Konflik Sosial. Jurnal Ilmiah Hubungan 
Internasional, O(0), 39-45. https://doi.org/10.26593/jihi.v1i1.3867.39-45

Setiati, S., \& Azwar, K. M. (2020). COVID-19 and Indonesia. Acta Medica Indonesiana, 52(1), 84-89. Retrieved from

http://www.actamedindones.org/index.php/ijim/article/view/1426

Setiawan, J. L. (2006). Willingness to seek counselling, and factors that facilitate and inhibit the seeking of counselling in Indonesian undergraduate students. British Journal of Guidance \& Counselling, 34(3), 403-419. https://doi.org/10.1080/03069880600769654

Song, X., Anderson, T., Himawan, L., McClintock, A., Jiang, Y., \& McCarrick, S. (2019). An Investigation of a Cultural Help-Seeking Model for Professional Psychological Services With U.S. and Chinese Samples. Journal of Cross-Cultural Psychology, 50(9), 1027-1049. https://doi.org/10.1177/0022022119878506

Spiker, D. A., Berney, E. C., Hammer, J. H., \& Jensen, K. C. (2020). Maintaining the Relationship: Relational Schemas and Women's Intent to Seek Couple Therapy. Counseling Psychologist, 48(6), 801-825. https://doi.org/10.1177/0011000020918400

Stevens, J. P. (2012). Applied Multivariate Statistics For The Social Sciences (5th ed.). London: Routledge. Retrieved from

https://books.google.com/books?hl=en\&lr=\&id=oIeDhzDebKwC\&oi=fnd\&pg=PR1\&dq $=$ james + p. + stevens + applied + multivariate $\&$ ots $=1 \mathrm{I} 5 \mathrm{Op} 8 \mathrm{Cwba \& sig}=\mathrm{V} 01 \mathrm{zwCI} 9 \mathrm{NDGd} 1 \mathrm{nB}$ Vw-7D987DuVg

Topkaya, N., Vogel, D. L., \& Brenner, R. E. (2017). Examination of the Stigmas Toward Help-seeking Among Turkish College Students. Journal of Counseling \& Development, 95(2), 213-225. https://doi.org/10.1002/jcad.12133

Vogel, D. L., Wade, N. G., \& Haake, S. (2006). Measuring the self-stigma associated with seeking psychological help. Journal of Counseling Psychology, 53(3), 325-337. https://doi.org/10.1037/0022-0167.53.3.325

Wang, C., Pan, R., Wan, X., Tan, Y., Xu, L., Ho, C. S., \& Ho, R. C. (2020). Immediate Psychological Responses and Associated Factors during the Initial Stage of the 2019 Coronavirus Disease (COVID-19) Epidemic among the General Population in China. International Journal of Environmental Research and Public Health, 17(5), 1729. https://doi.org/10.3390/ijerph17051729

WHO. (2020a). Mental health and psychosocial considerations during the COVID-19 outbreak. Retrieved from https://apps.who.int/iris/bitstream/handle/10665/331490/WHO-2019-nCoVMentalHealth-2020.1-eng.pdf

WHO. (2020b). WHO Coronavirus Disease (COVID-19) Dashboard. Retrieved August 7, 2020, from https://covid19. who.int/?gclid=CjwKCAjw1K75BRAEEiwAd41h1LScEOrKDB8t3DW chdWjtExpu4VsF_9OOHi3eU0ZlHasNGj_06wAkBoCO3AQAvD_BwE

Wilson, C. J., Deane, F. P., Ciarrochi, J. V, \& Rickwood, D. (2005). Measuring help-seeking intentions: Properties of the General Help-seeking Measuring help-seeking intentions: Properties of the General Help-seeking Questionnaire Questionnaire. Retrieved from https://ro.uow.edu.au/hbspapers/1527

Wind, T. R., Rijkeboer, M., Andersson, G., \& Riper, H. (2020, April 1). The COVID-19 
pandemic: The 'black swan' for mental health care and a turning point for e-health. Internet Interventions. Elsevier B.V. https://doi.org/10.1016/j.invent.2020.100317

Wulandari, P., \& Hidayat, R. (2020). General Anxiety Disorder-Related Coronavirus Disease-19 Outbreak in Indonesia: A Case Report. Open Access Macedonian Journal of Medical Sciences, 8(T1), 36-38. https://doi.org/10.3889/oamjms.2020.4762

Xiang, Y. T., Yang, Y., Li, W., Zhang, L., Zhang, Q., Cheung, T., \& Ng, C. H. (2020, March 1). Timely mental health care for the 2019 novel coronavirus outbreak is urgently needed. The Lancet Psychiatry. Elsevier Ltd. https://doi.org/10.1016/S22150366(20)30046-8

Xiong, J., Lipsitz, O., Nasri, F., Lui, L. M. W., Gill, H., Phan, L., ... McIntyre, R. S. (2020). Impact of COVID-19 pandemic on mental health in the general population: A systematic review. Journal of Affective Disorders, 277, 55-64. https://doi.org/10.1016/j.jad.2020.08.001

Yap, M. B. H., Wright, A., \& Jorm, A. F. (2011). The influence of stigma on young people's help-seeking intentions and beliefs about the helpfulness of various sources of help. Social Psychiatry and Psychiatric Epidemiology, 46(12), 1257-1265. https://doi.org/10.1007/s00127-010-0300-5

Zhao, H., He, X., Fan, G., Li, L., Huang, Q., Qiu, Q., ... Xu, H. (2020). COVID-19 infection outbreak increases anxiety level of general public in China: involved mechanisms and influencing factors. Journal of Affective Disorders, 276, 446-452.

https://doi.org/10.1016/j.jad.2020.07.085 
Table 1. Demographic characteristics and predictors correlation toward GHSQ $(\mathrm{N}=1340)$.

\begin{tabular}{|c|c|c|c|c|c|c|}
\hline \multirow{2}{*}{ Demographic factors } & \multirow{2}{*}{$\mathrm{n}(\%)$} & \multicolumn{3}{|c|}{ GHSQ Score } & \multirow[b]{2}{*}{$r$} & \multirow{2}{*}{$\mathrm{p}$} \\
\hline & & $11-33$ n (\%) & $34-56 \mathrm{n}(\%)$ & $57-77 \mathrm{n}(\%)$ & & \\
\hline \multicolumn{7}{|l|}{ Age } \\
\hline $12-30$ & $1130(84.33)$ & $152(13.45)$ & $691(61.15)$ & $287(25.40)$ & \multirow{3}{*}{.070} & \multirow{3}{*}{.005} \\
\hline $31-50$ & $186(13.88)$ & $18(9.68)$ & $111(59.68)$ & $57(30.65)$ & & \\
\hline$>51$ & $24(1.79)$ & $1(4.17)$ & $13(54.17)$ & $10(41.67)$ & & \\
\hline \multicolumn{7}{|l|}{ Gender } \\
\hline Male & $369(27.54)$ & $48(13.01)$ & $229(62.06)$ & $92(24.93)$ & \multirow[t]{2}{*}{-.061} & \multirow[t]{2}{*}{.013} \\
\hline Female & $971(72.46)$ & $123(12.67)$ & $586(60.35)$ & $262(26.98)$ & & \\
\hline \multicolumn{7}{|l|}{ Education } \\
\hline High school or below & $520(38.81)$ & $89(17.12)$ & $312(60.00)$ & $119(22.88)$ & \multirow[t]{2}{*}{.121} & \multirow[t]{2}{*}{.000} \\
\hline College or above & $820(61.19)$ & $82(10.00)$ & $503(61.34)$ & $235(28.66)$ & & \\
\hline \multicolumn{7}{|l|}{ Occupation } \\
\hline Students & $738(55.07)$ & $126(17.07)$ & $450(60.98)$ & $162(21.95)$ & \multirow{4}{*}{.101} & \multirow{4}{*}{.000} \\
\hline Teacher & $332(24.78)$ & $19(5.72)$ & $202(60.84)$ & $111(33.43)$ & & \\
\hline Medic & $35(2.61)$ & $3(8.57)$ & $16(45.71)$ & $16(45.71)$ & & \\
\hline Other & $235(17.54)$ & $23(9.79)$ & $147(62.55)$ & $65(27.66)$ & & \\
\hline \multicolumn{7}{|l|}{ Living in infected area } \\
\hline No & $437(32.61)$ & $53(12.13)$ & $261(59.73)$ & $123(28.15)$ & \multirow[t]{2}{*}{-.020} & \multirow[t]{2}{*}{.236} \\
\hline Yes & 903 (67.39) & $118(13.07)$ & $554(61.35)$ & $231(25.58)$ & & \\
\hline \multicolumn{7}{|l|}{ Smoking } \\
\hline No & 1247 (93.06) & $162(12.99)$ & $752(60.30)$ & 333 (26.70) & \multirow[t]{2}{*}{-.017} & \multirow[t]{2}{*}{.269} \\
\hline Yes & $93(6.94)$ & $9(9.68)$ & $63(67.74)$ & $21(22.58)$ & & \\
\hline \multicolumn{7}{|l|}{ Alcohol use } \\
\hline No & $1316(98.21)$ & $169(12.84)$ & 797 (60.56) & $350(26.60)$ & \multirow[t]{2}{*}{-.062} & \multirow[t]{2}{*}{.011} \\
\hline Yes & 24 (1.79) & $2(8.33)$ & $18(75.00)$ & $4(16.67)$ & & \\
\hline \multicolumn{7}{|l|}{ Fear } \\
\hline Low & $651(48.58)$ & $119(18.28)$ & $407(62.52)$ & 125 (19.20) & \multirow{3}{*}{.337} & \multirow{3}{*}{.000} \\
\hline Moderate & $563(42.01)$ & $47(8.35)$ & $360(63.94)$ & $156(27.71)$ & & \\
\hline High & $126(9.40)$ & $5(3.97)$ & $48(38.10)$ & $73(57.94)$ & & \\
\hline Anxiety & & & & & & \\
\hline Low & $1156(86.27)$ & $163(14.10)$ & $718(62.11)$ & 275 (23.79) & & \\
\hline Moderate & $154(11.49)$ & $7(4.55)$ & $88(57.14)$ & $59(38.31)$ & .243 & .000 \\
\hline Hifh & $30(2.24)$ & $1(3.33)$ & $9(30.00)$ & $20(66.67)$ & & \\
\hline
\end{tabular}

Note, the predictors were assigned to the specific value as follows:

Gender (Female = 1, Male = 2); Age $(12-30=1,31-50=2,>51=3)$; Education (High School or below $=1$, College or above $=2)$; Occupation $($ Student $=1$, Teacher $=2$, Medic $=$ 3 , other $=4)$; Living in infected area $(\mathrm{No}=1$, Yes $=2)$; Smoking $(\mathrm{No}=2$, Yes $=1)$; Alcohol use $($ No $=2$, Yes $=1)$; Fear $($ Low $=1$, Moderate $=2$, High $=3)$; and Anxiety $($ Low $=1$, Moderate $=2$, High $=3$ ). 
Table 2. The mean and SD of GHSQ $(\mathrm{N}=1340)$

\begin{tabular}{lll}
\hline \multirow{2}{*}{ GHSQ Domain } & \multicolumn{2}{c}{ Descriptive analysis results } \\
\cline { 2 - 3 } & Mean & SD \\
\hline Spouses (husband/wife or girlfriend) & 4.09 & 2.46 \\
Friends & 4.72 & 1.82 \\
Parents & 5.70 & 1.91 \\
family (other than parents) & 4.66 & 1.97 \\
mental health experts (counselors, psychiatrists, psychologists) & 4.76 & 2.07 \\
help by telephone & 4.56 & 2.06 \\
doctors & 5.26 & 2.00 \\
teachers & 3.96 & 1.98 \\
religious leaders (kyai, ulama, pastor and others) & 4.18 & 2.05 \\
social workers & 3.59 & 1.94 \\
Not interested to seek help & 2.50 & 1.95 \\
\hline
\end{tabular}

Note: Lower bound $=1$; Upper bound $=7$ 
Table 3. Multiple linear regression analysis $(\mathrm{N}=1340)$

\begin{tabular}{lll}
\hline \multirow{2}{*}{ Variable } & \multicolumn{2}{l}{ Multiple linear regression results } \\
\cline { 2 - 3 } & Beta & p-value \\
\hline Age & .054 & .042 \\
Gender & -.039 & .177 \\
Education & .088 & .002 \\
Occupation & .066 & .020 \\
Living in infected area & -.072 & .006 \\
Smoking & .027 & .365 \\
Alcohol use & -.052 & .059 \\
Fear & .318 & .000 \\
Anxiety & .033 & .316 \\
\hline
\end{tabular}


Table 4. Multivariate logistic regression analysis $(\mathrm{N}=1340)$

\begin{tabular}{|c|c|c|c|c|}
\hline \multirow{3}{*}{ Variables } & \multicolumn{4}{|c|}{ Multivariate logistic regression results } \\
\hline & \multirow{2}{*}{ OR } & \multicolumn{2}{|c|}{$95 \% \mathrm{CI}$} & \multirow{2}{*}{ p-value } \\
\hline & & Lower & Upper & \\
\hline Age & 1.295 & .959 & 1.747 & .091 \\
\hline Gender & 1.036 & .748 & 1.436 & .830 \\
\hline Education & 1.130 & .835 & 1.529 & .428 \\
\hline Occupation & 1.097 & .968 & 1.245 & .148 \\
\hline Living in infected area & .763 & .576 & 1.011 & .060 \\
\hline Smoking & .785 & .429 & 1.436 & .432 \\
\hline Alcohol use & 1.008 & .305 & 3.334 & .990 \\
\hline Fear & 1.062 & 1.035 & 1.090 & .000 \\
\hline Anxiety & 1.045 & 1.003 & 1.088 & .037 \\
\hline
\end{tabular}


Conflict of Interest

\section{Declaration of Competing Interest}

The authors declare no conflict of interest. 


\section{Contributors}

APM and MIK conceptualized and designed the study. APM, MW, MIK, AIC, KH, IFZ, SB, MNL, RM, NH, AH, AZ, YEP, WJS, and DBI disseminated the questionnaire. APM, MW, and AIC analyzed and interpret the data. APM and AIC wrote the manuscript. MW, MIK, KH, IFZ, SB, MNL, RM, NH, AH, AZ, YEP, WJS, and DBI read then provide critical review. All authors read the final manuscript and approved to submit the manuscript to Journal of Affective Disorders.

\section{Data availability}

The datasets obtained in the current study are available from the corresponding author upon request

\section{Role of funding source}

None

\section{Acknowledgments}

None

\section{Supplementary materials}

None 